\title{
Editorial
}

\section{The Role of National Guidelines While Staying Abroad with an Acute Stroke}

\author{
Shuhei Okazaki Marc Fatar \\ Department of Neurology, Universitätsmedizin Mannheim, University of Heidelberg, Mannheim, Germany
}

If you suffer an acute stroke in a foreign country, what kind of treatment can you expect? Since the latter half of the 1990s, evidence-based guidelines of the management of acute stroke were developed independently in several countries, such as Europe [1], USA [2], and Japan [3]. Because these guidelines were generally established according to published clinical studies, most of the recommendations are similar to one another. However, there are a few, but important differences among these guidelines due to the geological and racial differences [4] existing across countries. For example, in Japan, because of racial differences in blood coagulation-fibrinolysis factors [5] and the results of the preceding domestic clinical trials [6], thrombolytic therapy with $0.6 \mathrm{mg} / \mathrm{kg}$ alteplase is recommended in the Japanese guidelines and approved as the best medical treatment only by the national health insurance. Similar low-dose alteplase regimens are also performed in many Asian countries [7]. From the point of view of 'personalized medicine', however, they do provoke the question of how to treat foreign travelers best in a globalized world. If an American/European tourist suffers an acute ischemic stroke during a trip to Japan, should he receive a thrombolytic therapy with $0.6 \mathrm{mg} / \mathrm{kg}$ alteplase according to the Japanese guidelines? Conversely, should Asian patients in Europe be treated with low-dose regimens?

\section{KARGER}

E-Mail karger@karger.com

www.karger.com/ced
This situation reflects the history of IV thrombolysis for acute stroke treatment. In 1995, the NINDS trial first showed the efficacy of alteplase $(0.9 \mathrm{mg} / \mathrm{kg})$ for acute ischemic stroke. The dosage of $0.9 \mathrm{mg} / \mathrm{kg}$ was decided according to the two pilot studies $[8,9]$, despite any attempts to investigate the apparent dose effect of alteplase in these studies. Similarly, in Japan, although observational studies showed the efficacy and the safety of thrombolysis with $0.6 \mathrm{mg} / \mathrm{kg}$ alteplase [6], a randomized controlled trial testing this low-dose regimen was never performed. The rationale to use $0.6 \mathrm{mg} / \mathrm{kg}$ was based on the findings of another recombinant tissue plasminogen activator (duteplase) trial for acute stroke [6] and alteplase trials for acute myocardial infarction [5]. There is also a controversy over the optimal dosage of alteplase in other Asian countries. The Taiwan Thrombolytic Therapy for Acute Ischemic Stroke (TTT-AIS) study raises the possibility that $0.9 \mathrm{mg} / \mathrm{kg}$ alteplase may cause a higher incidence of symptomatic intracranial hemorrhage and mortality than low-dose regimens in Chinese patients, especially in patients $\geq 70$ years old [10]. On the other hand, a more recent report from the Thrombolysis Implementation and Monitor of Acute Ischemic Stroke in China (TIMS-China) concluded that $0.9 \mathrm{mg} / \mathrm{kg}$ alteplase had a more favorable outcome than low-dose regimens in Chinese population [11]. 
At present, there are well-established evidences of $0.9 \mathrm{mg} / \mathrm{kg}$ alteplase in non-Asian populations. Therefore, non-Asian stroke patients might be treated with $0.9 \mathrm{mg} / \mathrm{kg}$ alteplase even if they suffer an acute ischemic stroke while staying in Asian countries. On the other hand, there is an ongoing discussion based on insufficient evidences about the optimal dosage of alteplase in Asian populations. A large randomized clinical trial (Enhanced Control of Hypertension and Thrombolysis in Stroke Disease (ENCHANTED) study: NCT 01422616) has been launched in Australia, Asia, Europe and South America to determine the optimal dose of alteplase. This study will answer the question whether we need to adjust the dosage of alteplase according to the race and ethnicity of patients. Subgroup analyses for Asian patients of the pooled randomized controlled trials of alteplase might also be helpful to address this question.

\section{Acknowledgement}

We thank Dr. Kazuo Minematsu (National Cerebral and Cardiovascular Center, Osaka, Japan) for his valuable discussions and remarkable insights.

\section{References}

1 Ringleb PA, Bousser M, Ford G, Bath P, Brainin M, Caso V, Cervera Á: Guidelines for management of ischaemic stroke and transient ischaemic attack 2008. Cerebrovasc Dis 2008;25:457-507.

2 Jauch EC, Saver JL, Adams HP, Bruno A, Connors JJB, Demaerschalk BM, Khatri P, McMullan PW, Qureshi AI, Rosenfield K, Scott PA, Summers DR, Wang DZ, Wintermark M, Yonas $\mathrm{H}$ : Guidelines for the early management of patients with acute ischemic stroke: a guideline for healthcare professionals from the American Heart Association/American Stroke Association. Stroke 2013;44:870-947.

-3 Shinohara Y, Yanagihara T, Abe K, Yoshimine T, Fujinaka T, Chuma T, Ochi F, Nagayama M, Ogawa A, Suzuki N, Katayama Y, Kimura A, Minematsu K: II. Cerebral infarction/transient ischemic attack (TIA). J Stroke Cerebrovasc Dis 2011;20:S31-S73.

4 Kern R, Nagayama M, Toyoda K, Steiner T, Hennerici MG, Shinohara Y: Comparison of the European and Japanese guidelines for the management of ischemic stroke. Cerebrovasc Dis 2013;35:402-418.
Ueshima S, Matsuo O: The differences in thrombolytic effects of administrated recombinant t-PA between Japanese and Caucasians. Thromb Haemost 2002;87:544-546.

6 Minematsu K, Toyoda K, Hirano T, Kimura K, Kondo R, Mori E, Nakagawara J, Sakai N, Shiokawa Y, Tanahashi N, Yasaka M, Katayama Y, Miyamoto S, Ogawa A, Sasaki M, Suga S, Yamaguchi T; Japan Stroke Society: Guidelines for the intravenous application of recombinant tissue-type plasminogen activator (alteplase), the second edition, October 2012: a guideline from the Japan Stroke Society. J Stroke Cerebrovasc Dis 2013;22:571-600.

7 Sharma VK, Ng KWP, Venketasubramanian N, Saqqur M, Teoh HL, Kaul S, Srivastava PM, Sergentanis T, Suwanwela N, Nguyen TH, Lawrence Wong KS, Chan BPL: Current status of intravenous thrombolysis for acute ischemic stroke in Asia. Int J Stroke 2011;6: 523-530.
$>8$ Brott TG, Haley EC, Levy DE, Barsan W, Broderick J, Sheppard GL, Spilker J, Kongable GL, Massey S, Reed R: Urgent therapy for stroke. Part I. Pilot study of tissue plasminogen activator administered within 90 minutes. Stroke 1992;23:632-640.

-9 Haley EC, Levy DE, Brott TG, Sheppard GL, Wong MC, Kongable GL, Torner JC, Marler JR: Urgent therapy for stroke. Part II. Pilot study of tissue plasminogen activator administered 91-180 minutes from onset. Stroke 1992;23:641-645.

10 Chao AC, Hsu HY, Chung CP, Liu CH, Chen $\mathrm{CH}$, Teng $\mathrm{MMH}$, Peng GS, Sheng WY, Hu $\mathrm{HH}$ : Outcomes of thrombolytic therapy for acute ischemic stroke in Chinese patients: the Taiwan Thrombolytic Therapy for Acute Ischemic Stroke (TTT-AIS) study. Stroke 2010;41:885-890.

11 Liao X, Wang Y, Pan Y, Wang C, Zhao X, Wang DZ, Wang C, Liu L, Wang Y: Standarddose intravenous tissue-type plasminogen activator for stroke is better than low doses. Stroke 2014;45:2354-2358. 